\title{
Study on Right and Obligation of Legal Bodies of School-enterprise Cooperation in Innovation and Entrepreneurship Education
}

\author{
Yuzhong Sun \\ Chongqing City Management College, Chongqing 401331, China.
}

Keywords: school-enterprise cooperation; innovation and entrepreneurship education model; right and obligation

\begin{abstract}
The main legal bodies of school-enterprise cooperation in innovation and entrepreneurship education not only include schools and enterprises, but also include government departments and students. According to the paradigm of law, this paper analyzes the rights and obligations of all bodies involved in the cooperation between school and enterprises in the current laws, regulations, rules and policies. It helps to clarify their power and responsibility boundaries, so as to promote the sound development of innovation and entrepreneurship education in higher vocational education.
\end{abstract}

\section{Introduction}

The essence of innovation and entrepreneurship education in higher vocational education is to cultivate the quality education for all students with the ability of lifelong sustainable development. It includes two aspects of innovation and entrepreneurship. The innovation is the intellectual support of entrepreneurship, and entrepreneurship is the way of innovation practice and realization. School-enterprise cooperation is the soul of higher vocational education, but also the soul of innovation and entrepreneurship education. Without school-enterprise cooperation, the innovation and entrepreneurship education in higher vocational education will lose its practical meaning. The cooperation between school and enterprise in innovation and entrepreneurship education is not simply a matter of civil law that is carried out on the basis of innovation, entrepreneurship and education cooperation between vocational colleges and enterprises. It takes place between government, vocational colleges, enterprises and students, and it is systematic legal behavior of personnel training. Therefore, the empirical analysis of combing the legal rights and obligations of the legal bodies of entrepreneurship and education in school-enterprise cooperation is the inevitable requirement of administering education by law.

\section{The Legal Bodies of School-enterprise Cooperation in Innovation and Entrepreneurship Education under the Rule of Law}

Innovation and entrepreneurship education have different meanings in different contexts of school-enterprise cooperation. To analyze school-enterprise innovation and entrepreneurship education under the rule of law, we should systematically study the provisions of the current education laws and regulations. The rights and obligations of the bodies of cooperation in entrepreneurship and entrepreneurship education are mainly fragmented in the Regulations on Vocational Education, the State Council and the regulations and policy documents of various ministries and local governments. By summarizing national laws, national policies and local normative documents, we can see that the cooperation between school and enterprises in innovation and entrepreneurship education is the key content of vocational education. It is not only the cooperation between enterprises and vocational colleges in the narrow sense, Is a model of vocational education determined by the essential characteristics of vocational education from the macro to the micro. Without the cooperation between school and enterprises, it often divorces from the actual needs of the enterprises and loses the purpose of innovation and undertaking education in vocational 
education and deviates from the goal of vocational education. Under the background of vigorously developing the background of innovation and entrepreneurship in vocational education in our country, the cooperation and innovation of universities and enterprises need normative guidance and specific financial policy support from the government. The innovation and entrepreneurship education of universities and enterprises can not make vocational colleges take a long- Situation, the application of professional knowledge and transformation of the industry, enterprises are not just consumer talent, but also industry knowledge and experience should be fed back vocational education, and actively participate in innovation and entrepreneurship education, to assume the social responsibility of vocational education. Vocational institutions should build their own core competitiveness, which should enable participating enterprises to truly benefit from cooperation in innovation, entrepreneurship and education so as to stimulate enterprises to participate more in their enthusiasm. Vocational education students are the end of school-enterprise cooperation in innovation and entrepreneurship education, that is, innovation and entrepreneurship education center. In the school-enterprise cooperation innovation and entrepreneurship education, students should make every effort to abide by the practice of professional ethics, and effectively enhance the ability of innovation and entrepreneurship. To sum up, the main body of the cooperative education between school and enterprises can be generally attributed to four categories from the macro level. One is government, the other is business, the third is vocational education and the fourth is vocational education. The above four main bodies can not be separated from school-enterprise cooperation and innovation and entrepreneurship education.

\section{The Legal Relationships of school-enterprise Cooperation in Innovation and Entrepreneurship Education under the Rule of Law}

Legal relationships in the innovation and entrepreneurship education of the school-enterprise cooperation are also a kind of social relationship, which are the mutual rights and obligations between the educational laws and regulations in the process of adjusting the social relations of vocational education. The legal relationships between school-enterprise cooperation are also composed of the three elements of the subject, content and object of the legal relationship between school and enterprise. Firstly, the legal relationships between schools and enterprises. Vocational schools and enterprises mainly determine the rights and obligations of both parties through the agreement of school-enterprise cooperation. The prerequisite for their signing the agreement of school-industry cooperation is that both parties have equal status and have true meaning. Therefore, the legal relationship between the two parties based on the agreement of school-enterprise cooperation It is a civil law relationship between equal subjects. Secondly, the legal relationship between the schools and students in innovation and entrepreneurship education. The nature of the legal relationship between vocational schools and students is divided into civil legal relations and educational administrative legal relations according to their different status in the legal relationship. ${ }^{[1]}$ Thirdly, the legal relationships between enterprises and students. Students are still during the study. In the innovation and entrepreneurship education activities that are carried out by school-enterprise cooperation, if students only participate in business activities as mock entrepreneurship, they can not establish labor contractual relationship with enterprises and do not have laborer status, so they should not enjoy labor status that can have the rights and obligations belonging to labor. ${ }^{[2]}$ However, if students start their own businesses or start a business with them, they naturally have the rights and obligations that ordinary civil subjects enjoy.

\section{The Rights and Obligations of Legal Bodies in Innovation and Entrepreneurship Education of School-enterprise Cooperation under Legal Empirical Analysis}

\subsection{In the legal level.}

The laws of our country have carried out relatively macroscopic provisions on the rights and 
obligations of all parties involved in the innovation and entrepreneurship education of school-enterprise cooperation and did not refer to the specific and specific rights and obligations. Our Constitution stipulates the right of "collective economic organizations, state enterprises and institutions and other social forces to hold various educational undertakings in accordance with the law," so that enterprises have the right to cooperate with vocational institutions. Articles 20 and 47 of the Education Law stipulate the government's obligation to develop vocational education and vocational training. Therefore, it is the government's obligation to encourage and support vocational education in terms of national policies. The above provisions also stipulate that the participation of industrial enterprises in vocational schools School innovation entrepreneurship education rights, but also the corporate sector to assume social responsibility obligations. Article 6 of the "Law of the People's Republic of China on Vocational Education" clearly stipulates that "trade organizations and enterprises and business organizations shall fulfill their obligation to carry out vocational education according to law." Article 47 of the "Employment Promotion Law" stipulates that "local people's governments at or above the county level Departments should encourage and instruct enterprises to strengthen vocational education and training according to market demand and industrial development. Party vocational and technical training institutions and enterprises should be in close contact with each other and implement the combination of industry and education to serve economic construction and train practical talents and skilled workers The article explicitly stipulates the obligation of government departments at or above the county level to strengthen vocational education and clearly stipulates the obligation of vocational colleges to strengthen the cooperation between schools and enterprises in innovative and pioneering education.

\subsection{In the national policy level.}

At the national policy level, the provisions on the rights and obligations of all parties involved in innovation and entrepreneurship education through school-enterprise cooperation have become more specific. For example, the "Decision of the State Council on Vigorously Developing Vocational Education" in 2005 regarded the development of vocational education as the implementation of the scientific concept of development as an important foundation for economic and social development and a strategic focus of education. Governments at all levels need to "strengthen the overall management of vocational education development plans, resource allocation, conditions and policies and measures, and provide strong public services and a good environment for the development of vocational education." "We must earnestly strengthen leadership over vocational education, The vocational education into the target management." In addition, it also stipulates that the education administrative department of the State Council shall take the obligation of "overall planning, comprehensive coordination and macro-management" of vocational education. Clearly require local governments above the county level to establish a system of joint meeting of vocational education departments. It clearly pointed out that vocational colleges and enterprises need close cooperation in industry "to vigorously promote the combination of work and study, school-enterprise cooperation training mode." In 2006, the Ministry of Education's "Opinion on the Combination of Work-study and Work-study in Vocational Colleges and Work-study Programs" stipulated the obligation to establish a long-term and stable system of organization and liaison between schools and enterprises. The 2010 National Medium and Long-Term Education Reform and Development Plan (2010-2020) stipulate the obligation of government leadership, industry guidance and enterprises to participate in the innovation and entrepreneurship education of school-enterprise cooperation.

\subsection{In the local regulations and departmental rules.}

Due to the lack of promulgation of the law on cooperation between schools and enterprises in vocational education, the local legislatures, state ministries and local governments have formulated more detailed documents to promote the rights and obligations of all parties involved in school-enterprise cooperation based on the development of vocational education. In order to promote the cooperation of school-enterprise innovation and entrepreneurship in higher vocational education, the Ministry of Finance and the State Administration of Taxation issued the Circular of the Ministry 
of Finance and the State Administration of Taxation on Taxation of Education on February 5, 2004, The document provides tax incentives for enterprises to participate in the school-enterprise cooperation in terms of revenues and expenditures, such as "exemption from business tax on income derived from engaging in technology development, technology transfer business and the related technical consultancy and technical service businesses in schools." Tertiary institutions and various vocational schools shall be exempt from paying enterprise income tax on the technical service income obtained through technology transfer, technical training, technical consultation, technical services and technical contracting of various industries. "' Taxpayers are exempt from non-profits in China's non-profit society Groups and state organs shall donate their donations to education in full before corporate income tax and personal income tax.” In response to the acceptance of student internships by the enterprises, the Ministry of Finance and the State Administration of Taxation have promulgated the Circular on Relevant Income Tax Policies for Enterprises 'Paying for Students' Internships ", the principle of rules Set the company to pay interns income tax deduction before tax. In 2007, the State Administration of Taxation issued the Administrative Measures on the Pre-tax Deduction of Corporate Payments for Intern Payments, which details the applicable scope and deduction conditions of tax deductions before tax. In terms of local laws and regulations and local government regulations, Henan Province, Guangxi Province, Jiangxi Province, Ningbo City, Chongqing Municipality, Shenzhen Municipality and Suzhou Municipality formulated the Notification and Opinions on Measures for Promoting the Cooperation of Schools and Enterprises through Vocational Education. Taking the "Measures for Promoting the Cooperation of School-enterprise in Henan Province in 2012" (for Trial Implementation) as an example, it considers that cooperation between schools and enterprises in vocational education means that vocational colleges and enterprises, public institutions and social organizations should take the lead in personnel training, staff training, scientific and technological innovation Cooperation with technical services, resource sharing and common development. "It is believed that the cooperation between schools and enterprises in vocational education is the common responsibility of governments, vocational colleges, trade associations and enterprises. It separately stipulates the rights and obligations of the government, vocational colleges, trade associations and enterprises respectively. For businesses to participate in school-enterprise cooperation, the provisions of enterprises and "vocational colleges to carry out various forms of cooperation" obligations, enterprises can share, shares and other forms, and vocational colleges jointly set up a school entity or independent vocational schools ; Enterprises should accept the practice of teachers and students, internships and Appropriate employment remuneration for on-the-job internship students; Encourage enterprises to provide subsidies and donations for vocational colleges; Enterprises that enjoy the relevant tax reduction and exemption policies that meet the conditions of tax relief. The same applies to these laws and regulations for the cooperation between school-enterprise innovation and entrepreneurship education.

\section{Conclusion}

College innovation and entrepreneurship education need enterprises' deep participation. It will be helpful to provide clear legal guidance for all parties to participate in innovation and entrepreneurship education and popularize the education of rule of law in innovation and entrepreneurship education by combing the legal relationships between them and analyzing their legal rights and obligations.

\section{Acknowledgements}

This paper is one of research achievements of the project of "Study on innovation and entrepreneurship model and practice of specialty of business management basing on the cooperation between colleges and companies" which is financially supported by the "Higher education teaching reform and research project of Chongqing Education Commission of 2016”. (Project Number:163233. Leading researcher: Yuzhong Sun.) 


\section{References}

[1] Z.Z.Cheng: Wuhan University LL.M. (2015).(In Chinese)

[2] F.M.Sun: Journal of Vocational Education Forum, (2011). No.8, p.75. (In Chinese) 